\title{
Early Regression of Spermatogenesis in Boars of an Inbred Duroc Strain Caused by Incident Orchitis/Epididymo-orchitis
}

\author{
Junko NOGUCHI ${ }^{1)}$, Michiko NAKAI ${ }^{2)}$, Kazuhiro KIKUCHI ${ }^{1)}$, Hiroyuki KANEKO ${ }^{1)}$ and \\ Noriaki IMAEDA ${ }^{3) \#}$ \\ 1)Division of Animal Sciences, National Institute of Agrobiological Sciences, Tsukuba, Ibaraki 305-8602, Japan \\ ${ }^{2)}$ Genetically Modified Organism Research Center, National Institute of Agrobiological Sciences, Tsukuba, Ibaraki 305- \\ 8602, Japan \\ ${ }^{3)}$ Gifu Prefectural Livestock Research Institute, Minokamo, Gifu 505-0037, Japan \\ \#Present: Faculty of Applied Biological Science, Gifu University, Gifu, Gifu 501-1193, Japan
}

\begin{abstract}
In the process of establishment of an inbred Duroc pig strain, males with size asymmetry of the testes were frequently observed. To clarify the possible causes of this asymmetry, we examined the testes and epididymides of 67 males of the F4-F7 generations at 35-100 weeks of age. Testicular weights showed a wide variation (120-610 g). When the weights of the testes were compared bilaterally, 35 of the 67 males showed more than a $10 \%$ difference. Histological examination of testes from this asymmetry group revealed a range of seminiferous tubule disruption including disappearance of all germ cells, but not Sertoli cells, in the epithelium. Focal lesions associated with the degenerated tubules were observed. Trends of incident fibrosis or hyalinization of these lesions were seen in aged males of the asymmetry group. Besides this abnormality of spermatogenesis, infiltration of mononuclear inflammatory cells around the tubule was frequently observed in the asymmetry group (32.9\%, compared with $1.6 \%$ in males showing testis symmetry). In severe cases, the inflammatory cells were concentrated in the intertubular region instead of Leydig cells. Cellular infiltration was also observed around the epididymal duct and blood vessels, but its incidence did not differ between the symmetry and asymmetry groups. Testicular testosterone levels were significantly increased in the asymmetry group, but those of $E_{2}$ and inhibin did not differ between the two groups. These histopathological features indicate that disruption of spermatogenesis after orchitis/epididymo-orchitis could induce testicular atrophy. Genetic predispositions for this trait may cause prevalent retrograde infections, resulting in orchitis/epididymo-orchitis.
\end{abstract}

Key words: Orchitis, Pig, Spermatogenesis, Testicular atrophy

(J. Reprod. Dev. 59: 273-281, 2013)

O nce established at the time of puberty, spermatogenesis is maintained throughout life and depends mainly on the self-renewal ability of spermatogenic stem cells. Spermatogenesis consists of spermatocytogenesis (proliferation and differentiation of spermatogonia into primary spermatocytes), meiosis and spermiogenesis (differentiation of spermatids into sperm). In each process, germ cells are sustained in a favorable environment created by Sertoli cells and other somatic cells under appropriate endocrine and paracrine regulation $[1,2]$. Immune privilege in the testis is a current topic of interest in relation to spermatogenesis. Despite the antigenic activity of spermatogenic germ cells and their appearance long after maturation of the immune system, germ cells are protected from autoimmune attack $[3,4]$. The milieu surrounding germ cells is prerequisite for sustaining spermatogenesis, and therefore you may say that male reproduction does hang, not stay, in balance.

In livestock and domestic animals, males whose semen quality has been confirmed are selected as sires for producing offspring. On

Received: November 20, 2012

Accepted: January 23, 2013

Published online in J-STAGE: February 22, 2013

(C)2013 by the Society for Reproduction and Development

Correspondence: J Noguchi (e-mail: jgucci@nias.affrc.go.jp) the other hand, especially in Japan, limited numbers of cases are available for investigation of impaired semen quality in males that are not selected to be sires and sires that become sterile at a reproductive age. In humans, semen is clinically evaluated to assess reproductive ability. If semen quality is insufficient, testicular biopsy is indicated for subsequent application of artificial reproductive techniques, rather than for diagnosis aimed at treatment of spermatogenetic impairment, to allow couples to produce babies. Since livestock animals have long reproductive periods like humans, etiological studies of reproduction in male animals could be of worth not only for improving efficiency in animal industries but also for understanding the pathogenicity of human reproduction.

In 1998, Gifu Prefectural Livestock Research Institute (Minokamo, Gifu, Japan) began to establish an inbred pig strain from a pair of Duroc pigs. The siblings were mated for several generations basically by brother-sister mating. During this process, males with size asymmetry of the testes were frequently observed. Therefore, we planned to examine the testes and epididymides of the males of all generations histologically to clarify the reasons for this testis asymmetry. The results revealed that incident orchitis/epididymo-orchitis in this strain induced testicular atrophy with impaired spermatogenesis. We consider that there may be genetic predispositions for this trait, and that the boars could become a useful model for allowing a better 
understanding of the nature of immune privilege and inflammation in the testis.

\section{Materials and Methods}

\section{Animals and tissue collection}

This survey was undertaken using male pigs that were produced and kept with standard feed for the swine industry at Gifu Prefectural Livestock Research Institute (Minokamo, Gifu, Japan). Siblings were subjected to brother-sister mating, except for a few that were used for crossbreeding between generations to obtain sufficient numbers of siblings. Fluid portions of ejaculated semen were collected from males when they reached reproductive age (approximately 26 weeks) to check the state of spermatogenesis. Boars were sacrificed at slaughterhouses in accordance with the Slaughterhouse Act of Japan. When testes were confirmed to be normal (i.e., not showing cryptorchidism), they were collected along with the epididymis. After trimming off the excess connective tissue, the testes were weighed. A portion of the testes and epididymides was fixed immediately in Bouin's fixative. For fluoroimmunoassays, another portion of the testis was collected, frozen immediately and then kept at $-80 \mathrm{C}$ until use.

\section{Morphological analysis}

The fixed samples were dehydrated and then embedded in paraffin. Tissue sections $4 \mu \mathrm{m}$ thick were stained with hematoxylin and eosin or Azan. Immunohistochemistry was undertaken as described previously [5] using anti-cytochrome P450 aromatase mouse IgG (MCA2077S, AbD Serotec, Kidlington, UK) and a Vectastain Elite ABC Kit (Vector Laboratories, Burlingame, CA, USA). For identification of $\mathrm{B}$ cells, sections that had been subjected to a blocking procedure were incubated with biotin-labeled anti-swine $\mathrm{IgG}$ (biotinylated goat IgG, Vector Laboratories) for $1 \mathrm{~h}$ at $37 \mathrm{C}$ and then reacted with an avidin-biotin peroxidase detection kit, as described previously.

\section{Hormone assays}

Each testis was weighed and then homogenized in 4 volumes of PBS (Dulbecco's PBS, Nissui, Tokyo, Japan) containing 0.5\% CHAPS and protease inhibitor cocktail (Roche Diagnostics, Mannheim, Germany) at $4 \mathrm{C}$. After centrifugation at $19,000 \times \mathrm{g}$ for $30 \mathrm{~min}$ at $4 \mathrm{C}$, the supernatant was collected and supplied for assays. Concentrations of total inhibin, testosterone and estradiol-17 $\beta$ were measured by fluoroimmunoassay as described previously [6].

\section{Statistical analysis}

Hormone assay data are presented as means \pm SD. The Student's $t$-test was used to compare the assay data between symmetry and asymmetry groups. Differences at $\mathrm{P}<0.05$ were considered to be significant.

\section{Results}

\section{General observations}

In this study, 67 adult boars ( 15 from the $4^{\text {th }}$ generation, 24 from the $5^{\text {th }}$ generation, 12 from the $6^{\text {th }}$ generation, and 16 from the $7^{\text {th }}$ generation) between 35 and 100 weeks of age were analyzed. Semen of the each animal was checked after 26 weeks of age, except for five males. Although one of the 62 males showed a low sperm concentration $\left(0.9 \times 10^{8}\right.$ sperm per $\left.\mathrm{ml}\right)$, the others had normal concentrations (over $1 \times 10^{8}$ sperm per $\mathrm{ml}$ ), thus confirming that spermatogenesis normally initiated. With regard to sperm viability, three out of the 62 males showed less than $60 \%$ viability, and another nine boars showed normal sperm concentrations $\left(2.8-10.0 \times 10^{8}\right.$ sperm per $\mathrm{ml})$, but the sperm were completely immotile.

Testicular weights showed variations. When the weights were compared bilaterally, marked asymmetry was detected (Fig. 1). Testes from 32 of the 67 males showed a difference of less than $10 \%$, but 35 males showed a weight difference of over $10 \%$. Among the 35 males with testis weight asymmetry, the difference was over $20 \%$ in 15 of them. The most typical case was testes weighing $380 \mathrm{~g}$ and $120 \mathrm{~g}$ (a 68\% difference between testes) in a 51-week-old male. According to data on cryptorchidism in males of this strain, testis weights have varied between 80 and $180 \mathrm{~g}$, and the mean \pm SD has been $116 \pm 38 \mathrm{~g}(\mathrm{n}=17)$. Comparable weights of the asymmetric small testes to those of cryptorchid testes, in which spermatogenesis was completely abolished, seemed to reflect markedly impaired spermatogenesis in the asymmetric testes.

\section{Histopathology of the testis}

General: Histological examinations revealed variable degrees of disruption in the seminiferous tubules, including a decreased number of germ cell layers in the epithelium, a Sertoli cell-only epithelium and tubule atrophy accompanied by fibrosis. Anatomically, the porcine testicular parenchyma is divided into lobules by fibrous septa, which are cords of connective tissue. In cases of severe spermatogenic disruption, most tubules in a lobule exhibited a lack of germ cells but contained Sertoli cells only in the epithelium. In slight or moderate cases, a few affected tubules were sparsely scattered in the lobules. The degree of impaired spermatogenesis in each testis is shown with symbols in Fig. 1. In most cases, the intertubular area was occupied by Leydig cells, despite presence of affected tubules. Exceptionally, however, infiltration of inflammatory cells was sometimes evident, as described below.

Acute lesions: Severe exfoliation of germ cells, possibly indicating an acute process of germ cell depletion, was detected in pig No. 163 at 36 weeks of age. The weights of the right and left testes were $190 \mathrm{~g}$ and $280 \mathrm{~g}$, respectively. In the right testis, sloughed elongated spermatids with a ball shape were observed in the lumina of tubules (Fig. 2A). This progressive disorder was observed throughout some lobules, whereas others contained tubules with various degrees of germ cell loss. Some of these tubules were associated with mononuclear inflammatory cells. Such cells were occasionally present inside the basement membrane, but did not protrude into the epithelium (Fig. 2b). In the left testis, tubules containing only Sertoli cells, and also nearly normal lobules, were observed (Fig. 2B). In the affected lobules, the intertubular region was occupied by inflammatory cells instead of Leydig cells. The ball-shaped sloughed germ cells were observed ipsilaterally in the lumen of the epididymal ducts in the caudal region (Fig. 2C). Poor sperm accumulation in the lumen was evident in the cauda and caput regions of the epididymis on both sides.

Chronic lesions: As seen in the testes of pig No. 609 at 41 weeks of age, a focal lesion with total tubule atrophy in the lobule was observed (Fig. 3A). Tubules in the lesion were small in diameter, irregularly 


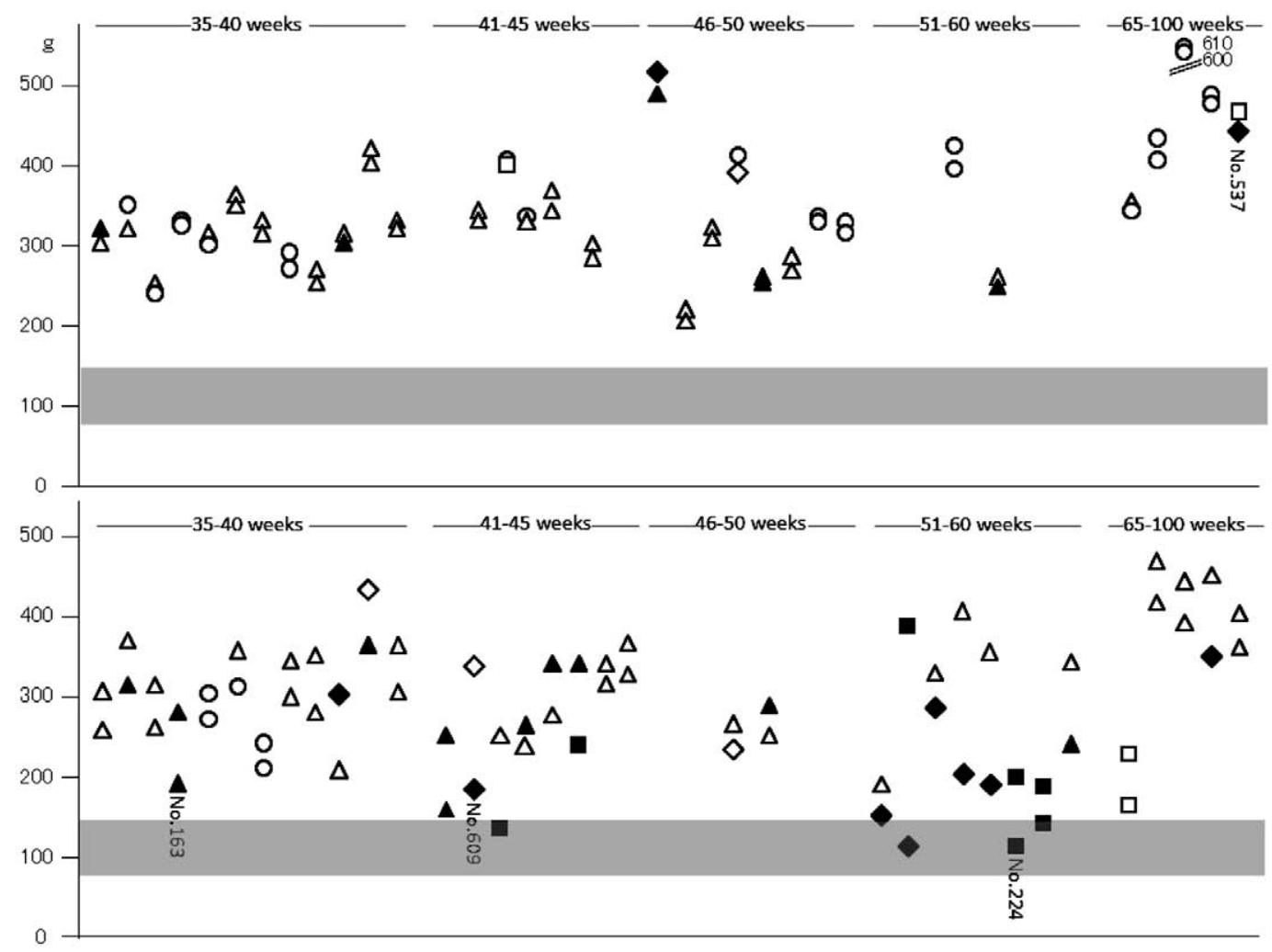

Fig. 1. Plot of individual testicular weights of 67 males of the inbred Duroc strain. Males with testes whose weights differed within $10 \%$ and those with testes whose weights differed by more than $10 \%$ are plotted in the upper (symmetry group) and lower (asymmetry group) panels, respectively. Individual males are arranged from left to right by age. Right and left testes are lined vertically with symbols showing effects on spermatogenesis. Testes with normal spermatogenesis $(O)$, spermatogenesis affected in less than $(\Delta)$ or more than $(\boldsymbol{\Delta})$ one tubule per field at $\times 100$ magnification, spermatogenesis affected in less than one tubule with less than one atrophic tubule $(\diamond)$, spermatogenesis affected in less than one tubule with more than one atrophic tubule $(\square)$, spermatogenesis affected in more than one tubule with less than one atrophic tubule $(\checkmark)$, and spermatogenesis affected in more than one tubule with more than one atrophic tubule (ם). Numbers of males are shown with their morphology in the figures.

shaped and surrounded by thickened fibrous septa. Leydig cells had disappeared, and instead, inflammatory cells including neutrophils with a typical nuclear shape occupied the intertubular area. Fibrosis in and around the focal lesion was evidenced by azan staining (Fig. $3 \mathrm{~B}$ and C; No. 224 at 55 weeks of age). Immunohistochemistry revealed morphologically distinguishable Leydig cells showing a positive reaction with anti-cytochrome $\mathrm{P} 450$ aromatase (Fig. $3 \mathrm{D})$, in accordance with previous reports $[7,8]$. Cells that were morphologically different from Leydig cells also exhibited a strong positive reaction in the focal lesions. These positive reactions were not absent in the negative control (lacking the primary antibody, data not shown). When the mirror section was incubated with biotin-labeled anti-pig $\operatorname{IgG}$, positive reactions were observed, indicating that these cells were IgG-producing cells, i.e., B lymphocytes (Fig. 3E). We did detect Alcian blue-positive cells, i.e., mast cells, in the testis but not TNF- $\alpha$-positive cells by immunohistochemistry (data not shown).

Another morphological feature of the focal lesions was hyalinization of the tubules, whose lumina were not easily recognizable and were occasionally filled with an eosinophilic substance (Fig. 3F; No. 537, at 95 weeks of age). Focal damage tended to be evident in relatively small testes (less than $200 \mathrm{~g}$ in weight) in the asymmetry group and was sometimes located adjacent to normal lobules.

Cellular infiltration: Besides the above morphopathology, infiltration was observed around the seminiferous tubules. In most cases, one or a few tubules per testicular section were affected. The inflammatory cells were accumulated in part of the tubule periphery (outer part of the peritubular myoid cell layer), and Leydig cells were preserved in the interstitium. Most of the affected tubules seemed to have normal spermatogenesis. With regard to the incidence of cellular infiltration, one out of 64 symmetrical testes (1.6\%) and 23 out of 70 asymmetrical testes $(32.9 \%)$ exhibited cellular infiltration in both faint and severe cases.

\section{Histopathology of the epididymis}

Epididymides from 67 males (129 samples in total, five samples from four males were not collected) were examined histologically. Normally, sperm were accumulated in the ductal lumen of the caput and cauda epididymis (Fig. 4A and B). The epithelium of the epididymal duct consists of two cell types: principal cells, which are columnar with stereocilia on the free surface, and basal cells, 

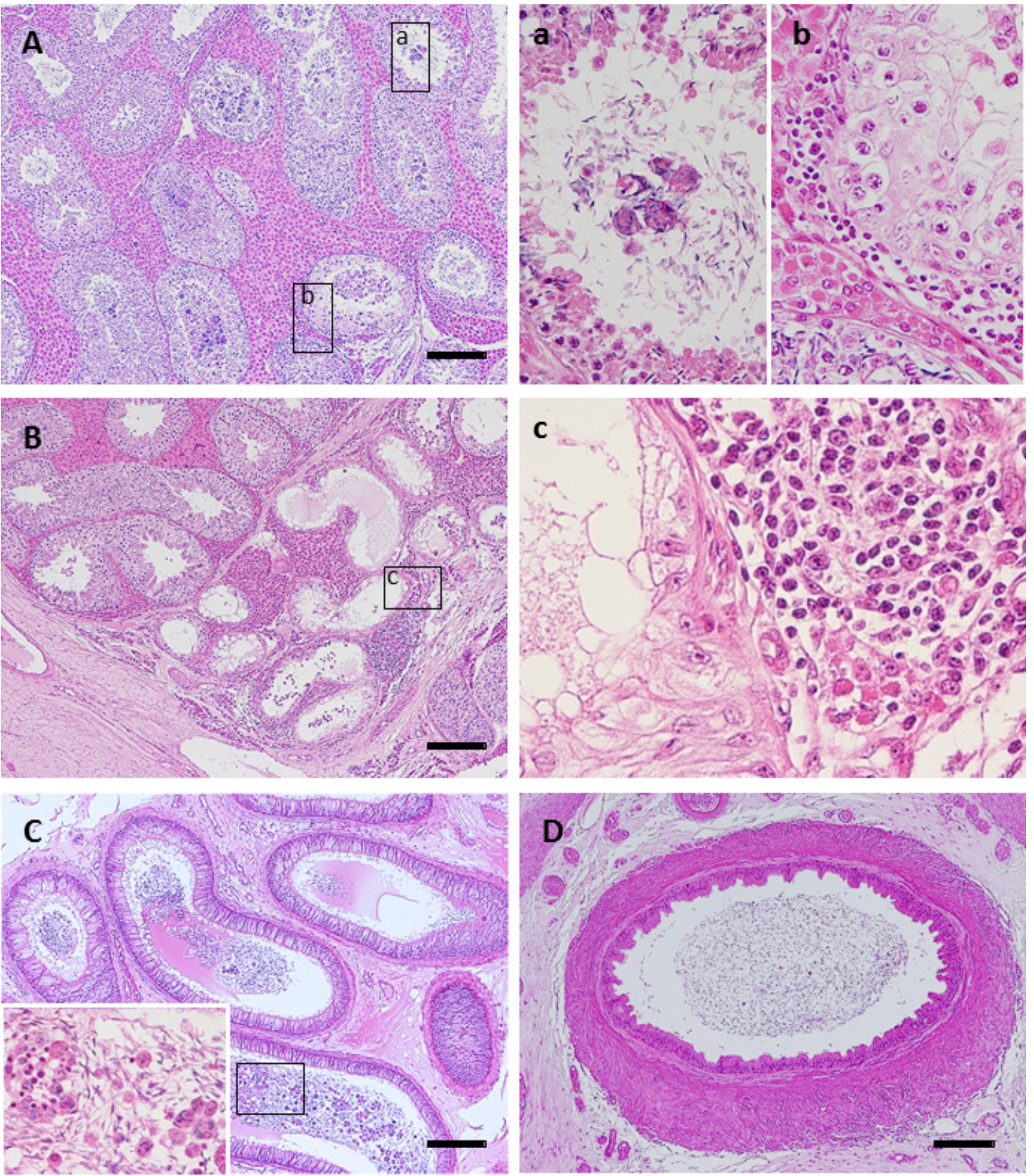

Fig. 2. Acute lesions of epididymo-orchitis. Morphology of the right (A) and left (B) testis and the caput (C) and caudal regions (D) of the right epididymis of male No. 163 (36 weeks old). Most of the seminiferous tubules in A showed progressive degeneration of the epithelium with germ cell desquamation (enlarged in a). Mononuclear cells invaded up to the basal cellular layer of the epithelium (enlarged in b). Leydig cells in the intertubular area seemed unaffected. In B, tubules that contained Sertoli cells and few spermatogonia in the epithelium were observed in the center lobule, possibly at the subacute phase. Inflammatory cells occupied in the intertubular area (enlarged in c). Note that the lobule on the left side seemed normal. Abundant desquamation of germ cells seen in the testis was reflected in the lumen of the caput region of the ipsilateral epididymis (C, inset). No marked changes were observed in the caudal epididymis apart from impaired accumulation of sperm (D). Scale bar $=200 \mu \mathrm{m}$.

which are oval or conical cells with sparse cytoplasm (Fig. 4C and D). Besides these two cell types, intraepithelial lymphocytes with round or ovoid dark nuclei and bright cytoplasm were present among the principal cells.
Fewer sperm were accumulated in the lumen of the epididymis when spermatogenesis in the ipsilateral testis was affected. Cellular debris, presumably derived from sloughed germ cells, was also observed in the lumen. Cellular infiltration in the epididymis was observed 

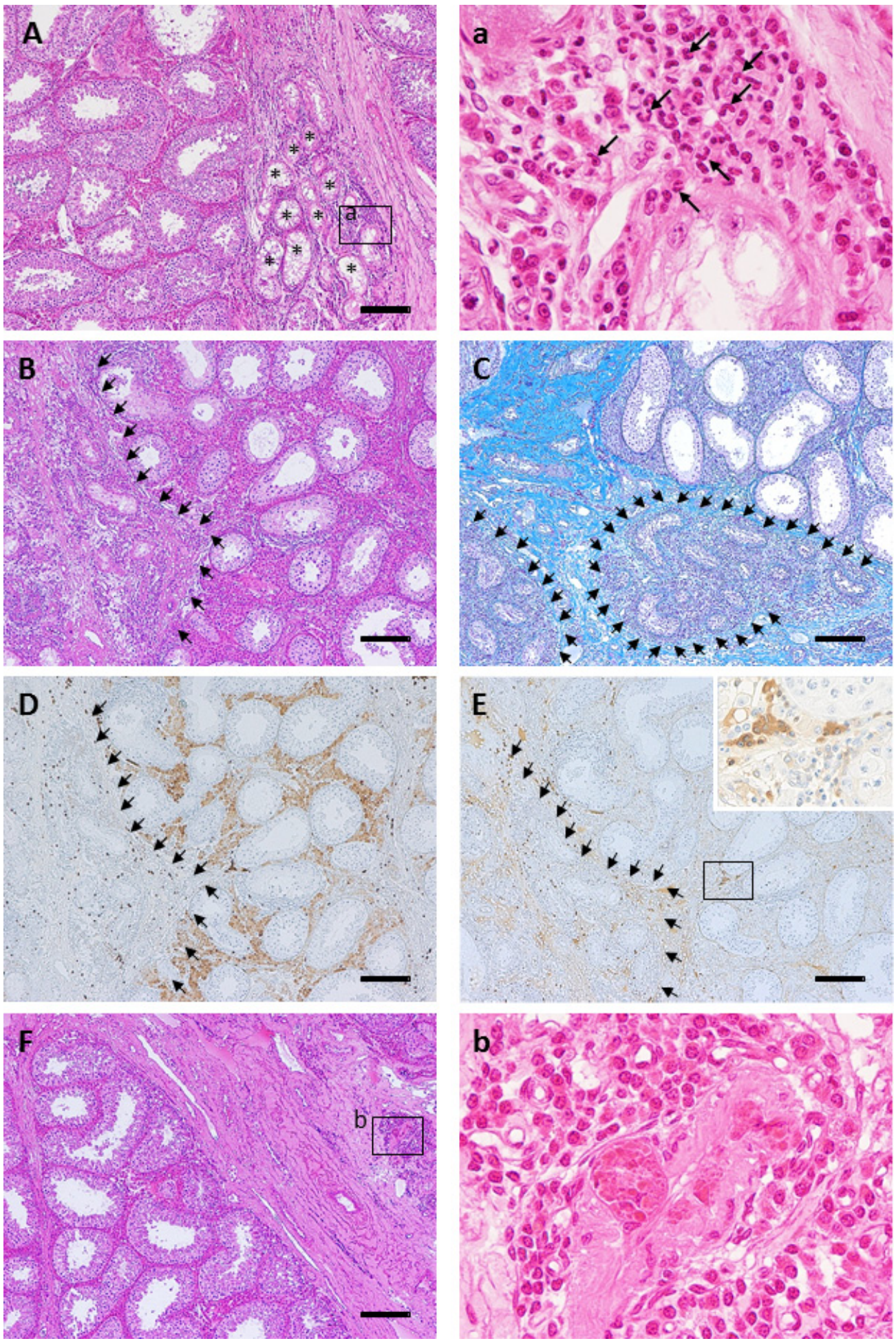

Fig. 3. Chronic lesions of orchitis. Testicular morphology of males Nos. 609 (41 weeks old, asymmetric smaller testis; panel A), 224 (55 weeks old, asymmetric smaller testis; panels B-E) and 537 (95 weeks old, smaller testis; panel F). A cohort of atrophic tubules showing a decrease in diameter was observed (A, asterisks). The intertubular areas were occupied by inflammatory cells. Neutrophils with unequivocal nuclear morphology were included in the area of infiltration (a, arrows). Atrophic tubules in the focal lesion (indicated by arrows in B-E) were small in diameter, and the lumen structure was not recognizable. Interstitial fibrosis was conspicuous in an azan-stained section (C). Immunohistochemistry with anti-cytochrome P450 aromatase antibody showed disappearance of Leydig cells in the focal lesion (D). Incubation of a mirror section of D with biotinylated anti-pig IgG antibody demonstrated B lymphocytes scattered in the focal lesion (E). Note accumulation of B lymphocytes around the seminiferous tubules (inset of E). Patchy lesion accompanying destruction of the tubules was bordered by a normal lobule (F). Hyalinization of the tubule (b). Scale bar $=200 \mu \mathrm{m}$. 

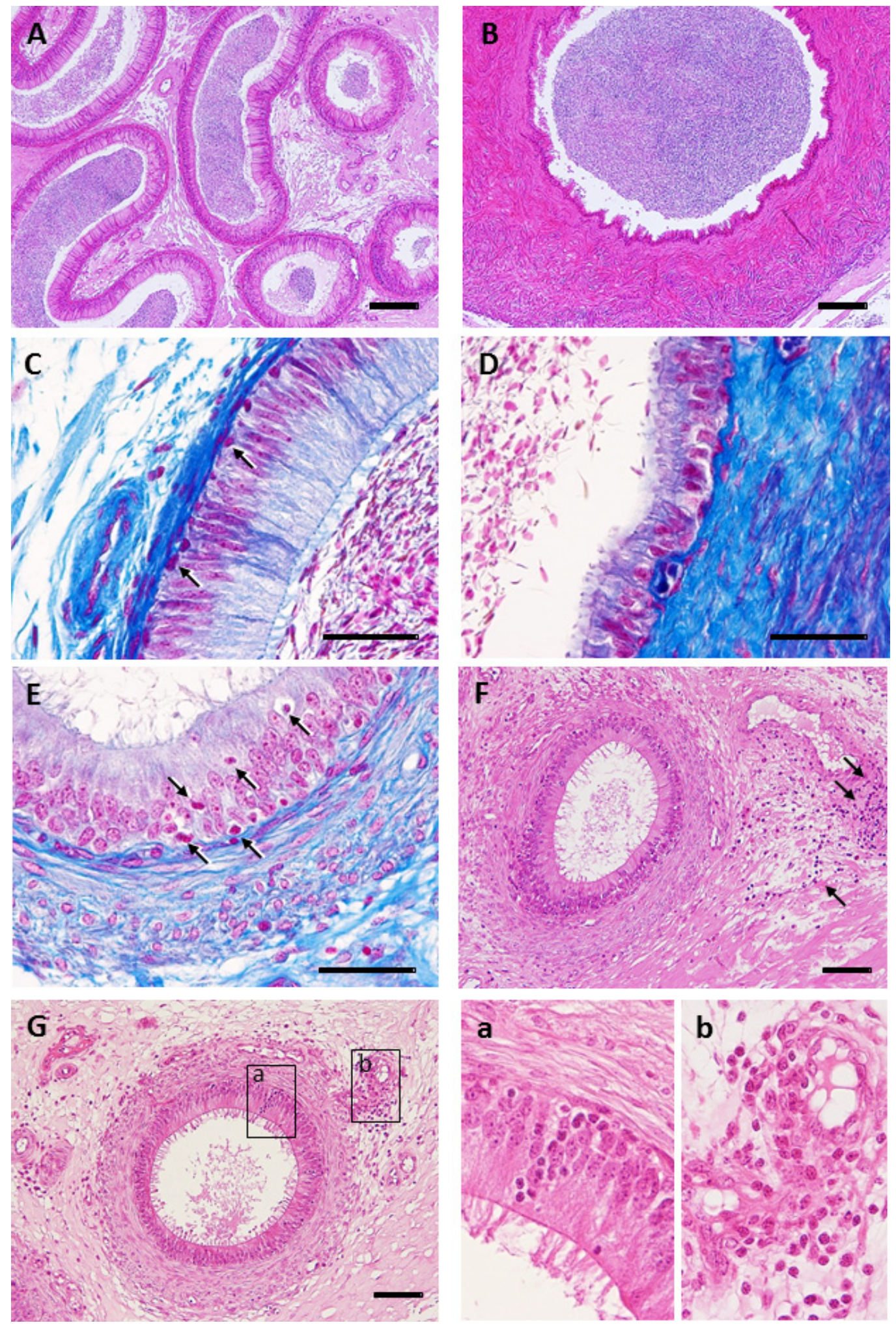

Fig. 4. Lesions of the epididymis. Morphology of the caput and cauda epididymis of males Nos. 537 (95 weeks old; panels A-D) and 224 (55 weeks old; panels E-G). C-E: Azan staining. Male No. 537 showed a normal morphology in both the caput (A and C) and caudal (B and D) regions. Sufficient accumulation of sperm was seen in the ductal lumen. Arrows in panel C indicate basal cells, which are elemental cells of the epithelium. Typical pathological morphology of the caput epididymis is evident in E-G. Arrows in E and panel a indicate invasion of inflammatory cells into the epithelium. Arrows in F and panel b indicate cuffing of blood vessels with inflammatory cells. Poor accumulation of sperm was evident in the lumen. Scale bars in A, B, F and G indicate $200 \mu \mathrm{m}$, and those in C, D and E indicate $40 \mu \mathrm{m}$. 
in both the symmetry and asymmetry groups ( 10 out of 62 samples and 13 out of 67 samples, respectively). The inflammatory cells had accumulated outside the periphery of the tunica muscularis or the epithelium (Fig. 4E). In some cases, protrusion of the cells toward the lumen was observed in the epithelium. A cuff of inflammatory cells was observed in blood vessels located near the duct (Fig. 4F and $\mathrm{G}$ ) in a total of 18 of 129 epididymides.

\section{Hormone levels}

Testes from eight boars in the symmetry group and 10 in the asymmetry group were subjected to assays of testosterone, estradiol$17 \beta$ and total inhibin. For reference, four cryptorchid testes and 12 testes from six Large White boars were also employed. The results are shown in Table 1. No significant difference was detected in the testicular concentrations of the inhibin and estradiol-17 $\beta$, whereas a significant difference was detected in the testosterone concentration between two groups. The individual testosterone concentrations were within a wide range in both groups (45.4-122.2 $\mathrm{ng} / \mathrm{ml}$ in the symmetry group and $44.2-176.1 \mathrm{ng} / \mathrm{ml}$ in the asymmetry group). Relationships between degrees of defect in spermatogenesis and testicular testosterone levels were not detected.

\section{Discussion}

Histological examinations showed that the marked incidence of testis size asymmetry in this Duroc strain was due to testicular atrophy after sexual maturation. Differences in the weights of the bilateral testes reflected the degree of disruption of spermatogenesis. To our knowledge, this is the first report to describe early regression of spermatogenesis in domestic animals. Sires are required to have sufficient fertility for the reproductive period of their life. Early regression of spermatogenesis negatively influences reproduction and production efficiency. In general, boars are selected as sires after checking of their semen quality. It is assumed that little emphasis has been placed on whether fertility is maintained, perhaps because of a belief that spermatogenesis remains efficient throughout life. Early regression of spermatogenesis could have been a feature of our Duroc strain, and perhaps has a genetic predisposition. However, it is conceivable that this trait might be a new characteristic that needs to be considered when estimating the reproductive performance of prospective sires.

A tendency for chronic orchitis was observed in the asymmetry group (23 out of 70 testes, $32.9 \%$ ). Etiologically, infections with viruses, bacteria and protozoa, physicochemical agents, autoimmune mechanisms and other nonclassifiable factors have been indicated as causative of disease $[9,10]$. Morphopathological characteristics as well as the frequent incidence of epididymitis in this group are suggestive of infectious orchitis. To date, several swine infections have been shown to cause orchitis or epididymo-orchitis and reduction of semen quality. These include pseudorabies (Aujeszky's virus [11]), porcine rubulavirus ("blue eye" disease virus [12]), porcine reproductive and respiratory syndrome (PPRS) virus $[13,14]$ and trypanosomiasis due to Trypanosoma brucei brucei [15]. However, it is unlikely that these infectious agents would have been responsible for the orchitis in the present study because they are specific pathogens and the boars used in this study had been kept under strictly controlled
Table 1. Concentrations of inhibin, testosterone and estradiol-17 $\beta$ in testes from males in the symmetry and asymmetry groups

\begin{tabular}{lcccc}
\hline & $\begin{array}{c}\text { Number of } \\
\text { testes }\end{array}$ & $\begin{array}{c}\text { Inhibin } \\
(\mathrm{ng} / \mathrm{ml})\end{array}$ & $\begin{array}{c}\text { Testosterone } \\
(\mathrm{ng} / \mathrm{ml})\end{array}$ & $\begin{array}{c}\text { Estradiol-17 } \\
(\mathrm{ng} / \mathrm{ml})\end{array}$ \\
\hline Symmetry & 16 & $25.4 \pm 5.3$ & $78.4 \pm 20.4$ & $15.8 \pm 9.8$ \\
Asymmetry & 20 & $25.4 \pm 5.6$ & $100.6 \pm 34.0^{*}$ & $16.4 \pm 5.5$ \\
\hline Cryptorchid & 4 & $27.4 \pm 4.2$ & $118.2 \pm 54.0$ & $19.0 \pm 3.1$ \\
Large White & 12 & $21.4 \pm 2.9$ & $94.6 \pm 31.4$ & $7.6 \pm 3.9$ \\
\hline
\end{tabular}

Mean \pm SD. No significant differences in the three kinds of hormones were detected between the groups. Data for testes from cryptorchid and Large White males are shown for reference. *Significantly different between the symmetry and asymmetry groups $(\mathrm{P}<0.05)$.

conditions. Besides these specific pathogens, many sorts of virus have been isolated from the testis and semen of mammals, and some of them have been shown to cause disease [16]. None of the boars examined in this study had suffered symptomatic diseases, but they might have harbored asymptomatic systemic infections with unknown pathogens, and these could have been responsible for orchitis or epididymo-orchitis.

Retrograde infections with common urinary pathogens are another possible explanation for the orchitis/epididymo-orchitis observed in the present study. The prevalence rate of retrograde infection and its influence on male fertility in livestock animals have not been discussed extensively. In humans, inflammations of the testis and other parts of the male reproductive tract are accepted to be an important etiological factor of infertility, and thus nonspecific bacterial orchitis is of some concern $[17,18]$. The incidence of epididymitis in boars of the symmetry and asymmetry groups was comparable, possibly reflecting retrograde infection that remained in the epididymis and did not spread up to the testis. Otherwise, the part of the sample examined might have been free of orchitis. Even if this were the case, any influence on the testis in the symmetry group would not have been significant, since the presence of epididymitis was not associated with the weight of the ipsilateral testis (less than $10 \%$ ).

Noninfectious orchitis is also of some concern when interpreting the present results. The testis is an immune-privileged tissue in which germ cells with antigenic activity are protected against autoimmune reactions [3, 4]. Once this well-organized condition is disturbed by any factors, the activated immune system will begin to attack antigenic germ cells. For example, activation of immune functions after exposition of syngeneic testicular germ cells is suggested to be responsible for orchitis/epididymitis after vasectomy or vas-reversal in humans and nonhuman primates [9, 19, 20]. Allergic orchitis is also incidental to some genetic conditions in mice [21], dogs [22] and minks [23]. Similar conditions of autoimmune orchitis are mimicked in mice by repeated injections of live germ cells without adjuvants. The resulting testicular morphopathology is similar to that which was observed here, although it does have several different features, including deposit of immunoglobulin around the seminiferous tubules $[9,21,23]$ and accumulation of inflammatory cells around the rete testis [24-26]. Different influences of activated immune functions in the testis and epididymis might be expressed in a species-specific manner, and thus autoimmune orchitis/epididymo-orchitis must be considered in the present context. 
The severely affected testes exhibited focal lesions of lobules in which all the tubules showed atrophy and fibrosis was observed. As shown in Fig. 3, such lesions were located among normal lobules. This distribution pattern of lesions is suggestive of the features of canalicular infections. We demonstrated the presence of B lymphocytes and mast cells in the lesions (data not shown). The latter cells secrete serine protease tryptase, an enzyme that facilitates fibroblast proliferation and collagen production $[27,28]$, resulting in tubule fibrosis and hyalinosis. Abnormal counts and distributions of immune-competent cells have been demonstrated in the testes of infertile men $[9,29$, 30]. It is noteworthy that orchitis/epididymo-orchitis tends to lead to scar formation without repair of spermatogenesis. Ludwig et al. [31] demonstrated persistent testicular inflammation in mice that could depend on immune responses activated by initial infectious acute orchitis. Therefore, prevention and early diagnosis of inflammation as well as treatment to eradicate the pathogen are important for maintenance of spermatogenesis.

Asymmetric testes showed higher levels of testosterone and similar levels of estradiol-17 $\beta$ and inhibin compared with the symmetrical tests. Although it is not clear whether these levels were brought about by the increased secretion, reduced testicular circulation or both, they evidenced that the affected spermatogenesis was not caused by impaired secretion of the hormones. Currently, the presence of anti-sperm antibodies may be a possible key to early diagnosis. The presence of such antibodies in the circulation has been demonstrated in models of infectious epididymo-orchitis [32-34]. Culminations of anti-sperm antibodies related and unrelated to vasectomy/vas-reversal have been reported in infertile men [35-37]. In a subsequent study, we plan to compare antibody titers at the point of sexual maturation and later in association with semen quality and testicular morphology.

In conclusion, the Duroc boars seem to acquire a genetic predisposition for orchitis/epididymo-orchitis, with a negative influence on spermatogenesis. Future studies to clarify the pathogenesis and causative genetic factors for orchitis/epididymo-orchitis would not only yield a better understanding of reproductive issues in livestock animals but would also provide an insight into the synergistic importance of the immune system and spermatogenesis.

\section{Acknowledgment}

The authors thank Ms M Nagai at the National Institute of Agrobiological Sciences for technical assistance.

\section{References}

1. Sharpe RM. Regulation of spermatogenesis. In: Knobil E, Neil JD (eds.), The Physiology of Reproduction, $2^{\text {nd }}$ eds. New York: Raven Press; 1994: 1363-1434.

2. de Kretser DM, Loveland KL, Mainhardt A, Simorangkir D, Wreford N. Spermatogenesis. Human Reprod 1998; 13(Suppl 1): 1-8. [CrossRef]

3. Fijak M, Meinhardt A. The testis in immune privilege. Immunol Rev 2006; 213: 66-81. [Medline] [CrossRef]

4. Fijak M, Bhushan S, Meinhardt A. Immunoprivileged sites: the testis. Methods Mol Biol 2011; 677: 459-470. [Medline] [CrossRef]

5. Okada K, Kimura M, Moriyama Y, Nakai M, Kikuchi K, Kaneko H, Kunieda T, Baba T, Noguchi J. Expression analysis of MIF4GD in the rat testis. J Reprod Dev 2011; 57: 256-261. [Medline] [CrossRef]

6. Kaneko H, Noguchi J, Kikuchi K, Todoroki J, Hasegawa Y. Alterations in peripheral concentrations of inhibin A in cattle studied using a time-resolved immunofluorometric assay: relationship with estradiol and follicle-stimulating hormone in various reproductive conditions. Biol Reprod 2002; 67: 38-45. [Medline] [CrossRef]

7. Carreau S, Genissel C, Bilinska B, Levallet J. Sources of oestrogen in the testis and reproductive tract of the male. Int J Androl 1999; 22: 211-223. [Medline] [CrossRef]

8. Fraczek B, Kotula-Balak M, Wojtusiak A, Pierscinski A, Bilinska B. Cytochrome P450 aromatase in the testis of immature and mature pigs. Reprod Biol 2001; 1: 51-59. [Medline]

9. Mikuz G, Damjanov I. Inflammation of the testis, epididymis, peritesticular membranes, and scrotum. Pathol Annul 1982; 17: 101-128. [Medline]

10. Schuppe HC, Meinhardt A. Immune privilege and inflammation of the testis. In: Markert UR (ed.), Immunology of Gametes and Embryo Implantaion. Vol 88. Basel: Karger; 2005: $1-14$.

11. Hall LB Jr, Kluge JP, Evans LE, Hill HT. The effect of pseudorabies (Aujeszky's) virus infection on young mature boars and boar fertility. Can J Comp Med 1984; 48: 192-197. [Medline]

12. Ramirez-Mendoza H, Hernandez-Jauregui P, Reyes-Leyva J, Zenteno E, MorenoLopez J, Kennedy S. Lesions in the reproductive tract of boars experimentally infected with porcine rubulavirus. J Comp Pathol 1997; 117: 237-252. [Medline] [CrossRef]

13. Prieto C, Suarez P, Bautista JM, Sanchez R, Rillo SM, Simarro I, Solana A, Castro JM. Semen changes in boars after experimental infection with porcine reproductive and respiratory syndrome (PRRS) virus. Theriogenology 1996; 45: 383-395. [Medline] [CrossRef]

14. Sur JH, Doster AR, Christian JS, Galeota JA, Wills RW, Zimmerman JJ, Osorio FA. Porcine reproductive and respiratory syndrome virus replicates in testicular germ cells, alters spermatogenesis, and induces germ cell death by apoptosis. $J$ Virol 1997; 71: 9170-9179. [Medline]

15. Omeke BCO, Igboeli G. Disruption of spermatogenesis in boars sub-clinically infected with Trypanosoma brucei brucei. Anim Reprod Sci 2000; 63: 197-204. [Medline] [CrossRef]

16. Dejucq N, Jegou B. Viruses in the mammalian male genital tract and their effects on the reproductive system. Microbiol Mol Biol Rev 2001; 65: 208-231. [Medline] [CrossRef]

17. Weidner W, Krause W, Ludwig M. Relevance of male accessory gland infection for subsequent fertility with special focus on prostatitis. Hum Reprod Update 1999; 5: 421-432. [Medline] [CrossRef]

18. Schuppe HC, Meinhardt A, Allam JP, Bergmann M, Weidner W, Haidl G. Chronic orchitis: a neglected cause of male infertility? Andrologia 2008; 40: 84-91. [Medline] [CrossRef]

19. Tung KSK, Alexander NJ. Monocytic orchitis and aspermatogenesis in normal and vasectomized rhesus macaques (Macaca mulatta). Am J Pathol 1980; 101: 17-29. [Medline]

20. Goldacre MJ, Wotton CJ, Seagroatt V, Yeates D. Immune-related disease before and after vasectomy: an epidemiological database study. Hum Reprod 2007; 22: 1273-1278. [Medline] [CrossRef]

21. Dooher GB, Artzt K, Bennett D, Hurtenbach U. Observations on autoimmune orchitis in sterile mice carrying a recessive lethal mutation at the $\mathrm{T} / \mathrm{t}$ complex exhibiting spontaneous allergic orchitis. J Reprod Fertil 1981; 62: 505-511. [Medline] [CrossRef]

22. Fritz TE, Lombard LS, Tyler SA, Norris WP. Pathology and familial incidence of orchitis and its relation to thyroiditis in a closed beagle colony. Exp Mol Pathol 1976; 24: 142-158. [Medline] [CrossRef]

23. Tung KSK, Teuscher LEC, Meng A, Blaustein JC, Kohno S, Howell R. The black mink (Mustela Vison) A natural model of immunologic male infertility. J Exp Med 1981; 154: 1016-1032. [Medline] [CrossRef]

24. Itoh M, Hiramine C, Hojo K. A new model of autoimmune orchitis induced by immunization with viable syngeneic testicular germ cells alone. I. Immunological and histologica studies. Clin Exp Immunol 1991; 83: 137-142. [Medline] [CrossRef]

25. Itoh M, De-Rooij D, Takeuchi Y. Mode of inflammatory cell infiltration in testes of mice injected with syngeneic testicular germ cells without adjuvant. J Anat 1995; 187: 671-679. [Medline]

26. Naito M, Itoh M. Patterns of infiltration of lymphocytes into the testis under normal and pathological conditions in mice. Am J Reprod Immunol 2008; 59: 55-61. [Medline] [CrossRef]

27. Abe M, Kurosawa M, Ishikawa $\mathbf{O}$, Miyachi Y, Kido H. Mast cell tryptase stimulates both human dermal fibroblast proliferation and type I collagen production. Clin Exp Allergy 1998; 28: 1509-1517. [Medline] [CrossRef]

28. Temkin V, Kantor B, Weg V, Hartman ML, Levi-Schaffer F. Tryptase activates the mitogen-activated protein kinase/activator protein-1 pathway in human peripheral blood eosinophils, causing cytokine production and release. J Immunol 2002; 169: 2662-2669. [Medline]

29. Meineke V, Frungieri MB, Jessberger B, Vogt H, Mayerhofer A. Human testicular mast cells contain tryptase: increased mast cell number and altered distribution in the testes of infertile men. Fertil Steril 2000; 74: 239-244. [Medline] [CrossRef]

30. Frungieri MB, Calandra RS, Lustig L, Meineke V, Kohn FM, Vogt H, Mayerhofer A. Number, distribution pattern, and identification of macrophages in the testes of infertile men. Fertil Steril 2002; 78: 298-306. [Medline] [CrossRef] 
31. Ludwig M, Johannes S, Bergmann M, Failing K, Schiefer HG, Weidner W. Experimental Escherichia coli epididymitis in rats: a model to assess the outcome of antibiotic treatment. BJU International 2002; 90: 933-938. [Medline] [CrossRef]

32. Hackett RA, Huang TW, Berger RE. Experimental Escherichia coli epididymitis in rabbits. Urology 1988; 32: 236-240. [Medline] [CrossRef]

33. Lekili M, Tekgul S, Ergen A, Tasar C, Hascelik G. Acute experimental unilateral orchitis in the rabbit and its effect on fertility. Int Urol Nephrol 1992; 24: 291-297. [Medline] [CrossRef]

34. Greskovich F, Mathur S, Nyberg JR, Collins BS. Effect of early antibiotic treatment on the formation of sperm antibodies in experimentally induced epididymitis. Arch Androl
1993; 30: 183-191. [Medline] [CrossRef]

35. el-Demiry MI, Elton R, Hargreave TB, James K, Busuttil A, Chisholm GD. Immunocompetent cells in human testis in health and disease. Fertil Steril 1987; 48: 470-479. [Medline]

36. Lenzi A, Gandini L, Lombardo F, Rago R, Paoli D, Dondero F. Antisperm antibody detection: 2. Clinical, biological, and statistical correlation between methods. Am J Reprod Immunol 1997; 38: 224-230. [Medline] [CrossRef]

37. Gubin DA, Dmochowski R, Kutteh WH. Multivariant analysis of men from infertile couples with and without antisperm antibodies. Am J Reprod Immunol 1998; 39: 157-160. [Medline] [CrossRef] 